mg at month 3 and 5 (0-7.5) $\mathrm{mg}$ at month 6; PDN was stopped in 3 patients ( 1 at month 3,1 at month 6,1 at month 12) due to optimal disease control. CNK was temporarily held-off in 3 patients (zoster reactivation, 1; prostatitis, 1; mild leukopenia, 1). We observed no case of primary inefficacy

Conclusion: Our real-life data confirm that CNK is highly effective and safe in AOSD treatment and has significant steroid-sparing effects. CNK showed its efficacy both as first-line therapy and after other bDMARDs failure, also in patients who have previously failed IL-1 inhibition through ANK

References:

[1] Cavalli G, et al. Treating rheumatological diseases and co-morbidities with interleukin-1 blocking therapies. Rheumatology (2015)

[2] Cavalli G, et al. Efficacy of Canakinumab as First-Line Biologic Agent in Adult-Onset Still's Disease. Arthritis Res Ther (2019)

Disclosure of Interests: Alessandro Tomelleri: None declared, Corrado Campochiaro Speakers bureau: Novartis, Pfizer, Roche, GSK, SOBI, Giacomo De Luca Speakers bureau: SOBI, Novartis, Celgene, Pfizer, MSD, Nicola Farina: None declared, Elena Baldissera Speakers bureau: Novartis, Pfizer, Roche, Alpha Sigma, Sanofi, Giulio Cavalli Speakers bureau: SOBI, Novartis, Pfizer, Lorenzo Dagna Grant/research support from: Abbvie, BMS, Celgene, Janssen, MSD, Mundipharma Pharmaceuticals, Novartis, Pfizer, Roche, SG, SOBI, Consultant of: Abbvie, Amgen, Biogen, BMS, Celltrion, Novartis, Pfizer, Roche, SG, and SOBI

DOI: 10.1136/annrheumdis-2020-eular.2352

\section{FRI0507 COLCHICINE INTOLERANCE IN FMF PATIENTS AND PRIMARY OBSTACLES FOR OPTIMAL DOSING}

H. Satış ${ }^{1}$ B. Armagan ${ }^{2}$, E. Bodakci ${ }^{3}$, N. Atas ${ }^{1}$, A. Sarı ${ }^{2}$, D. Yapar' ${ }^{1}$, N. S. Yasar Bilge $^{3}$, R. Bilici Salman', G. K. Yardımcı' ${ }^{2}$, H. Babaoglu' ${ }^{1}$, L. Kılıç², M. A. Ozturk', B. Goker ${ }^{1}$, S. Haznedaroglu ${ }^{1}$, U. Kalyoncu' ${ }^{2}$, T. Kaşifoğlu ${ }^{3}$, A. Tufan ${ }^{1} .{ }^{1}$ Gazi Univercity Faculty of Medicine Hospital, Ankara, Turkey; ${ }^{2}$ Hacettepe Univercity Faculty of Medicine, Ankara, Turkey; ${ }^{3}$ Eskisehir Univercity Faculty of Medicine Hospital, Eskişehir, Turkey

Background: Colchicine is the mainstay of treatment in FMF. However, in daily practice it is not easy to maintain effective colchicine doses in substantial number of patients, due to its side effects.

Objectives: It was aimed to investigate prevalence and risk factors for colchicine side effects that limit optimal drug dosing and permanent discontinuation.

Methods: All patients were recruited from "FMF in Central Anatolia" (FiCA) cohort, 915 adult subjects with minimum follow up time of 6 months and had compliance of treatment were included. Demographic and anthropometric data, FMF disease characteristics, disease severity, complications and treatment features were recorded on a web based registry. Prevalence of colchicine intolerance and characteristics of intolerant patients were analyzed.

Results: Effective colchicine doses cannot be maintained in $172(18.7 \%)$ subjects. Main side effects that limit optimal dosing were as follows; diarrhea in $99(10.8 \%)$, elevation in transaminases in $54(5.9 \%)$, leukopenia in $10(\% 1.1)$, renal impairment in $14(1.3 \%)$, myopathy in $5(0.5 \%)$ and allergic skin reaction in two. Colchicine had to be permanently ceased in $18(2 \%)$ patients because of serious toxicity. Male gender and obesity were found to be associated with liver toxicity and having normal body weight was associated with diarrhea. Chronic

Table 1. Prevalence of all side effects of colchicine and reasons for drug discontinuation

\begin{tabular}{lcc}
\hline Side effect & $\begin{array}{c}\text { All side effects } \\
\mathrm{N}=172^{*}\end{array}$ & $\begin{array}{c}\text { Permanent cessation } \\
\mathrm{N}=18^{*}\end{array}$ \\
\hline Diarrhea & 99 & 11 \\
Liver toxicity & 54 & 4 \\
Leukopenia & 10 & 1 \\
Muscle toxicity & 5 & 2 \\
Skin reaction & 2 & - \\
Nausea & 4 & - \\
Infertility & 2 & -
\end{tabular}

* some patients had more than one clinically significant side effect

Table 2. Disease course in colchicine tolerant and intolerant patients

\begin{tabular}{lccc}
\hline & $\begin{array}{c}\text { Colchicine Tolerant } \\
\mathrm{N}=743\end{array}$ & $\begin{array}{c}\text { Colchicine Intolerant } \\
\mathrm{N}=172\end{array}$ & $\mathrm{p}$ value \\
\hline Chronic inflammation & $115(15.4 \%)$ & $45(26.1 \%)$ & $<\mathbf{0 . 0 0 1}$ \\
Number of attacks in the last year & $4.05 \pm 6.08$ & $7.60 \pm 9.6$ & $<\mathbf{0 . 0 0 1}$ \\
Proteinuria & $44(5.9 \%)$ & $20(11.6 \%)$ & $\mathbf{0 . 0 2 5}$ \\
Amyloidosis & $33(\% 4.4)$ & $23(13.3 \%)$ & $<\mathbf{0 . 0 0 1}$ \\
ADDI (median) & $1(1)$ & $1(1)$ & $<\mathbf{0 . 0 0 1}$ \\
\hline
\end{tabular}

ADDI: auto-inflammatory disease damage index, FMF: familial Mediterranean fever inflammation and proteinuria were more common in colchicine intolerant patients and they had reported more frequent attacks compared to those tolerating optimal doses.

Conclusion: Colchicine intolerance is an important problem in daily clinical practice, mainly due to diarrhea and liver toxicity. Suboptimal colchicine dosing associated with complications.

References:

[1] Sönmez, H.E., E.D. Batu, and S. Özen, Familial Mediterranean fever: current perspectives. Journal of inflammation research, 2016. 9: p. 13.

[2] Sarı, I.., M. Birlik, and T. Kasifoğlu, Familial Mediterranean fever: an updated review. European journal of rheumatology, 2014. 1(1): p. 21.

[3] Ozen, S., et al., EULAR recommendations for the management of familial Mediterranean fever. Annals of the rheumatic diseases, 2016. 75(4): p. 644-651.

Disclosure of Interests: Hasan Satıș: None declared, Berkan Armagan: None declared, Erdal Bodakci: None declared, Nuh Atas: None declared, Alper Sarı: None declared, Dilek Yapar: None declared, Nazife Sule Yasar Bilge: None declared, reyhan bilici salman: None declared, Gözde Kübra Yardımcı: None declared, Hakan Babaoglu: None declared, Levent Kılıç: None declared, mehmet akif ozturk: None declared, Berna Goker: None declared, seminur haznedaroglu: None declared, Umut Kalyoncu Consultant of: Abbvie, Amgen, Janssen, Lilly, Novartis, UCB, Timuçin Kaşifoğlu: None declared, abdurrahman tufan: None declared

DOI: 10.1136/annrheumdis-2020-eular.3344

FRI0508
MALIGNANCY AND IGG4-RELATED DISEASE: THE
INCIDENCE, RELATED FACTORS AND PROGNOSIS
FROM A PROSPECTIVE COHORT STUDY IN CHINA.

H. Yang ${ }^{1}$, H. Tang ${ }^{1}$, P. Zhang ${ }^{1}$, Y. Fei ${ }^{1}$, H. Chen ${ }^{1}$, X. Zhang ${ }^{1}$, Y. Zhao ${ }^{1}$, F. Zhang ${ }^{1}$, W. Zhang ${ }^{1} .{ }^{1}$ Peking Union Medical College Hospital, Chinese Academy of Medical Sciences \& Peking Union Medical College, Beijing, China

Background: The association between IgG4-related disease (IgG4-RD) and malignancies is unclear. No epidemiological data for malignancies in Chinese IgG4-RD patients is available. It is also important to know the risk factors and prognosis for IgG4-RD patients harboring malignancies.

Objectives: To investigate the incidence, related factors and prognosis of IgG4related disease (IgG4-RD) with malignancies in the Chinese cohort.

Table 1. Baseline characteristic of IgG4-RD patients with malignancy

\begin{tabular}{|c|c|c|c|c|c|c|c|}
\hline Patient & Sex & KAge & $\begin{array}{l}\text { Age at } \\
\text { diagnosis of } \\
\text { lgG4-RD }\end{array}$ & $\begin{array}{l}\text { Age at } \\
\text { diagnosis } \\
\text { of malig- } \\
\text { nancy }\end{array}$ & $\begin{array}{l}\text { Serum } \\
\text { lgG4 }\end{array}$ & $\begin{array}{c}\text { Organs involvements of } \\
\text { IgG4-RD } \\
\left({ }^{*} \text { Organ with biopsy) }\right.\end{array}$ & $\begin{array}{l}\text { Sites of } \\
\text { malignancy }\end{array}$ \\
\hline $\mathrm{P} 1$ & $\mathrm{~F}$ & 59 & 58 & 54 & 1499 & $\begin{array}{l}\text { Parotid gland }{ }^{\star}, \text { salivary } \\
\text { gland }\end{array}$ & Breast cancer \\
\hline P2 & M & 74 & 66 & 68 & 10402 & $\begin{array}{l}\text { Pancreas, bile duct, retro- } \\
\text { peritoneal fibrosis, kidney, } \\
\text { prostate, lymph nodes }\end{array}$ & Rectal cancer \\
\hline P3 & M & 46 & 42 & 40 & 2630 & $\begin{array}{l}\text { Lacrimal gland, parotid } \\
\text { gland }\end{array}$ & Lipoblastoma \\
\hline P4 & $M$ & 70 & 68 & 64 & 5780 & $\begin{array}{l}\text { Pancreas, bile duct, lung, } \\
\text { prostate, lymph nodes }\end{array}$ & Thyroid carcinoma \\
\hline P5 & $\mathrm{F}$ & 62 & 61 & 61 & 11600 & $\begin{array}{l}\text { Pancreas, bile duct, salivary } \\
\text { gland }^{\star} \text {, periaortitis, lymph } \\
\text { nodes, pituitary }\end{array}$ & Thyroid carcinoma \\
\hline P6 & M & 72 & 68 & 68 & 3490 & $\begin{array}{l}\text { Pancreas, bile duct, lymph } \\
\text { nodes }\end{array}$ & Rectal cancer \\
\hline $\mathrm{P} 7$ & M & 60 & 58 & 58 & 2410 & $\begin{array}{l}\text { Pancreas, bile duct, lymph } \\
\text { nodes }\end{array}$ & Renal cancer \\
\hline P8 & M & 68 & 63 & 68 & 3520 & $\begin{array}{l}\text { Pancreas, bile duct, } \\
\text { retroperitoneal fibrosis, lung, } \\
\text { kidney, artery, lymph nodes }\end{array}$ & Rectal cancer \\
\hline P9 & $\mathrm{M}$ & 36 & 30 & 35 & 12400 & Pancreas, bile duct & Skin cancer \\
\hline P10 & M & 52 & 49 & 52 & 10000 & $\begin{array}{l}\text { Pancreas, parotid gland } \\
\text { lacrimal gland, lung, pros- } \\
\text { tate, lymph nodes }\end{array}$ & Thyroid carcinoma \\
\hline $\mathrm{P} 11$ & $\mathrm{~F}$ & 70 & 68 & 69 & 17300 & $\begin{array}{c}\text { Parotid gland, lacrimal } \\
\text { gland, salivary gland, sinus }\end{array}$ & Lung cancer \\
\hline $\mathrm{P} 12$ & $M$ & 82 & 79 & 79 & 58000 & Pancreas, lacrimal gland ${ }^{\star}$ & Colon cancer \\
\hline P13 & $\mathrm{F}$ & 50 & 49 & 45 & 14300 & Uterus*, ovary & $\begin{array}{l}\text { Ovarian } \\
\text { carcinoma }\end{array}$ \\
\hline P14 & $\mathrm{F}$ & 52 & 46 & 50 & 10000 & $\begin{array}{l}\text { Parotid gland }{ }^{\star}, \text { lacrimal } \\
\text { gland }\end{array}$ & Breast cancer \\
\hline P15 & $\mathrm{F}$ & 60 & 55 & 57 & 12500 & $\begin{array}{c}\text { Pancreas, parotid gland, } \\
\text { lacrimal gland, lymph nodes, } \\
\text { sinus }\end{array}$ & Lymphoma \\
\hline P16 & $M$ & 42 & 37 & 40 & 7490 & Lung*, lymph nodes & Renal cancer \\
\hline P17 & $\mathrm{M}$ & 71 & 68 & 69 & 415 & Pancreas*, bile duct & Prostate cancer \\
\hline
\end{tabular}


Table 2. Related factors for malignancies in patients with IgG4-RD

\begin{tabular}{|c|c|c|c|c|c|c|c|c|}
\hline \multicolumn{3}{|l|}{ Variables } & \multicolumn{3}{|c|}{ Univariate analysis } & \multicolumn{3}{|c|}{ Multivariate analysis } \\
\hline & & & \multicolumn{6}{|c|}{ Univariate OR $(95 \% \mathrm{Cl}) \mathrm{P}$-value Multivariate OR $(95 \% \mathrm{Cl}) \mathrm{P}$-value } \\
\hline \multirow{3}{*}{\multicolumn{4}{|c|}{$\begin{array}{l}\text { Head and Neck involvement } \\
\text { Autoimmune pancreatitis } \\
\text { Eosinophilia }\end{array}$}} & \multirow{3}{*}{\multicolumn{2}{|c|}{$\begin{array}{c}0.304(0.097-0.952) \\
5.359(1.651-17.393) \\
0.117(0.014-0.966)\end{array}$}} & 0.041 & \multirow{3}{*}{$\begin{array}{c}0.604(0.152-2.401) \\
6.230(1.559-24.907) \\
0.094(0.010-0.883)\end{array}$} & 0.474 \\
\hline & & & & & & 0.005 & & 0.010 \\
\hline & & & & & & 0.046 & & 0.039 \\
\hline matumentionent & $=$ & then & $=\infty$ & $\ln _{2=0}=0$ & 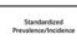 & \multicolumn{2}{|r|}{ Standardiced Provadence Incisence Rabo } & \\
\hline Simsongrions & 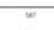 & 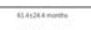 & " & 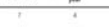 & thasoinsth & & $\longleftrightarrow 278$ & \\
\hline mintrancis & tis & tans- & " & " & namounes & & +-2 & -23.08 \\
\hline 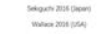 & is & smantine & n & : & 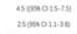 & & $\square_{25^{\circ}} 45$ & \\
\hline 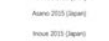 & $=$ & incia,-m & : & ; & zimonosese & & $\rightarrow 201$ & \\
\hline $\operatorname{lng}_{0} \sin \sin x$ & 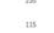 & nomimaxium & . & " & Ixsmo Isis & & $\rightleftarrows \stackrel{2.16}{\longrightarrow} 225$ & \\
\hline$n=m i s$ & 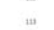 & 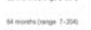 & . & " & sxmotints & & - 1.04 & \\
\hline 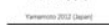 & $\%$ & nim & n & in & 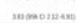 & & $\longrightarrow^{3.83}$ & \\
\hline
\end{tabular}

Figure 1. Standardized incidence ratios of malignancies in patients with IgG4-RD from different studies.

Methods: We prospectively analyzed the IgG4-RD patients recruited in Peking Union Medical College Hospital from January 2011 to August 2018 and identified patients diagnosed with IgG4-RD complicating malignancies. Data regarding demographics, clinical features, treatment and prognosis of IgG4-RD patients complicating malignancies were collected and compared to those of age- and sex-matched controls.

Results: Among the 587 Chinese patients with IgG4-RD, 17 malignancies were identified. Ten of them developed malignancy after the diagnosis of IgG4-RD, given a standard incidence ratio $(\mathrm{SIR})$ of $2.78(95 \% \mathrm{Cl} 1.33-5.12)$. Multivariate logistic analysis indicated that autoimmune pancreatitis $(\mathrm{OR}=6.230,95 \% \mathrm{Cl}$ $1.559-24.907, p=0.010$ ) was positively associated with malignancy, whereas eosinophilia $(\mathrm{OR}=0.094,95 \% \mathrm{Cl} 0.010-0.883, \mathrm{p}=0.039)$ was negatively related with malignancies. During a median follow-up period of $61.4 \pm 26.4$ months, all patients with IgG4-RD and malignancies survived.

Conclusion: An increased incidence of malignancy was found in Chinese IgG4-RD cohort. Autoimmune pancreatitis is a potential risk factor, whereas eosinophilia is a possible protective factor for complicating malignancies. References:

[1] Wallace, Z. S.,et al. Association of IgG4-Related Disease With History of Malignancy. Arthritis Rheumatol 68, 2283-2289 (2016).

[2] Hirano, K. et al. Incidence of malignancies in patients with IgG4-related disease. Intern. Med. 53, 171-176 (2014).

Disclosure of Interests: None declared

DOI: 10.1136/annrheumdis-2020-eular.4001

\section{FRI0509 COMPARISON OF MS SCORE AND HSCORE FOR THE DIAGNOSIS OF ADULT-ONSET STILL'S DISEASE ASSOCIATED MACROPHAGE ACTIVATION SYNDROME}

L. Zhang ${ }^{1}$, X. Yang ${ }^{1}$, T. LI ${ }^{1}$, S. Liu ${ }^{1} .{ }^{1} 1$ st affiliated hospital of Zhengzhou University, Zhengzhou, China

Background: Adult-onset Still's disease (AOSD) is a rare multisystemic auto-inflammatory disease.Macrophage activation syndrome (MAS) is a life-threatening complication of rheumatic disorders, including SJIA, adult-onset Still's disease (AOSD) and lupus. Many tools have been developed for the diagnosis of MAS, including HScore and MS score. Although some authors have tried to apply these tools for the diagnosis of ASOD-associated MAS, there are no studies comparing the diagnostic ability of HScore and MS score.

Objectives: We aimed to compare the capacity of HS score and MS score for the diagnosis of AOSD-associated MAS.

Methods: Patients diagnosed as AOSD during January,2012 and October,2019 in our hospital were retrospectively analyzed. Clinical and laboratory data were compared between patients with pure AOSD and those with AOSD associated MAS. HScore and MS score were calculated respectively and the diagnostic capacity of MAS was compared by means of receiver operating characteristic $(\mathrm{ROC})$ curve analysis.

Results: We included 174 patients with pure AOSD and 35 patients with AOSD-associated MAS. Patients with AOSD-associated MAS were younger than those with pure AOSD (32+/-11.4 yrs vs 36.9+/-13.5 yrs, $P=0.028)$. More death were observed among patients with AOSD-associated MAS (17.1\% vs $3.4 \%, P=0.001$ ). Patients with AOSD-associated MAS had higher HScore (median[range] 196[98-333] vs 68[33-156], $P<0.001$ ) and higher MS score (median[range] $1.05[-1.26-26.55]$ vs $-1.17[-1.26-2.52], P<0.001)$ than those with pure AOSD.The difference of different parameters of these two groups of patients

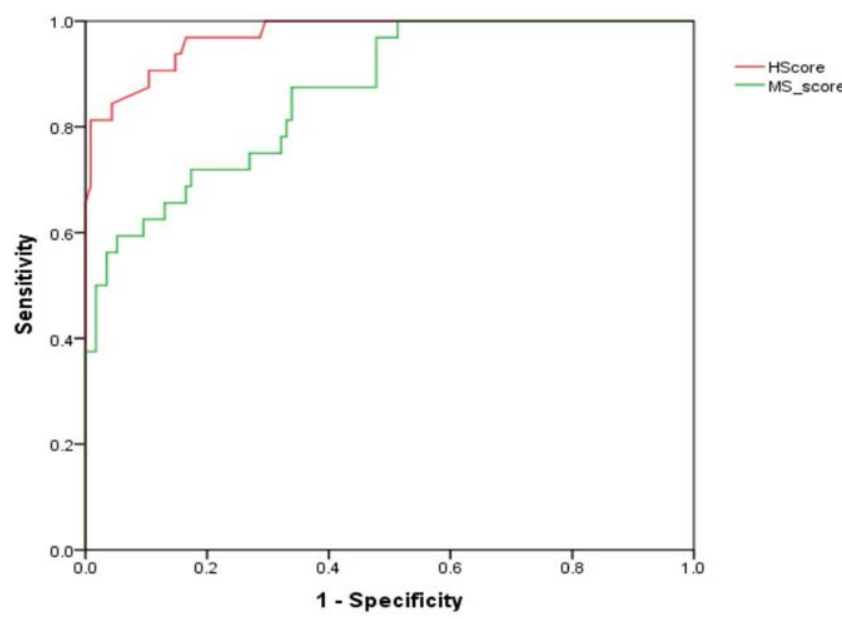

Figure 1. ROC curve of HScore and MS score. HScore $=120$, sensitivity $=90.6 \%$, specificity $89.6 \%$. MS score $=-0.45$, sensitivity $=75 \%$, specificity $=73 \%$. AUC-HScore $=0.973$, AUC-MS score $=0.865, P<0.001$

were detailed in Table 1 and Table 2. ROC curve analysis (Figure 1) revealed that HScore has stronger ability to diagnose AOSD-associated MAS compared with MScore ( $A U C=0.973$ and 0.865 for HScore and MS score repectively, $\mathrm{P}<0.001$ ). HScore $\geq 120$ perform best (sensitivity $90.6 \%$ and specificity $89.6 \%$ ). MS score $\geq-$ 0.25 yielded a sensitivity of $75 \%$ and a specificity of $73 \%$.

Conclusion: HScore seems to perform much better than MS score for the diagnosis of AOSD-associated MAS in our cohort.

References:

[1] Siddiqui M, Putman MS, Dua AB. Adult-Onset still's disease: current challenges and future prospects. Open Access Rheumatol 2016;8:17-22.

[2] Bracaglia C, Prencipe G, De Benedetti F. Macrophage activation syndrome: different mechanisms leading to a one clinical syndrome. Pediatr Rheumatol Online J 2017;15.

[3] Guilpain P, Le Quellec A. About the complexity of adult onset still's disease... and advances still required for its management. BMC Med 2017;15:5.

[4] Minoia F, Bovis F, Davì s, et al. Development and initial validation of the MS score for diagnosis of macrophage activation syndrome in systemic juvenile idiopathic arthritis.Ann Rheum Dis 2019;78:1357-1362.

[5] Fardet L, Galicier L, Lambotte O, et al. Development and validation of the HScore, a score for the diagnosis of reactive hemophagocyticsyndrome. Arthritis Rheumatol. 2014 Sep;66(9):2613-20.

[6] ED Batu, A Erden, E Seyhoğlu, etal. Assessment of the HScore for reactive haemophagocytic syndrome in patients with rheumatic diseases.Scand $J$ Rheumatol. 2017 Jan;46(1):44-48.

[7] Wang R, Li T, Ye S, et al. Application of MS score in macrophage activation syndrome patients associated with adult onset Still's disease. Ann Rheum Dis. 2019 Oct 14. pii: annrheumdis-2019-216286.

Disclosure of Interests: None declared

DOI: 10.1136/annrheumdis-2020-eular.4303

\section{FRIDAY, 05 JUNE 2020}

\section{Public health, health services research, and health economics}

\begin{tabular}{|l|l}
\hline FRI0510 & THE FREQUENCY OF CONTRACEPTION \\
DOCUMENTATION IN WOMEN ON AND OFF \\
TERATOGENIC ANTI-RHEUMATIC MEDICATIONS IN \\
THE RISE REGISTRY
\end{tabular}

M. Clowse ${ }^{1}, \mathrm{~J}_{\mathrm{LI}}{ }^{2}, \mathrm{M}$. Birru Talabi ${ }^{3}, \mathrm{~A}$. Eudy $^{1}, \mathrm{G}$. Schmajuk ${ }^{2} .{ }^{1}$ Duke University, Durham, United States of America; ${ }^{2}$ UC San Francisco, San Francisco, United States of America; ${ }^{3}$ UPMC, Pittsburgh, United States of America

Background: Several of the most commonly prescribed medications for women with rheumatic disease are teratogens, posing a risk for pregnancy loss and birth defects if taken in pregnancy. To prevent these life-altering complications, it is important that all women taking teratogenic medications avoid pregnancy through abstinence or contraception.

Objectives: We sought to understand the accessibility to contraceptive data within the RISE Registry and to test whether, compared to other women, 